\title{
Article \\ Arthrospira platensis Cultivation in a Bench-Scale Helical Tubular Photobioreactor
}

\author{
Alessandro Alberto Casazza ${ }^{1}\left(\mathbb{D}\right.$, Ricardo Pinheiro de Souza Oliveira ${ }^{2} \mathbb{D}^{\mathbb{D}}$, Milena Fernandes da Silva ${ }^{3} \mathbb{D}$, \\ Carlo Solisio ${ }^{1}$, Charles Bronzo Barbosa Farias ${ }^{4}\left(\mathbb{D}\right.$, Leonie Asfora Sarubbo ${ }^{5}$ (D) and Attilio Converti ${ }^{1, *(D)}$
}

1 Department of Civil, Chemical and Environmental Engineering, University of Genoa, Via Opera Pia 15, 16145 Genoa, Italy; alessandro.casazza@unige.it (A.A.C.); carlo.solisio@unige.it (C.S.)

2 Biochemical and Pharmaceutical Technology Department, Faculty of Pharmaceutical Sciences, São Paulo University, Av. Prof. Lineu Prestes, 580, Bl 16, São Paulo 05508-900, Brazil; rpsolive@usp.br

3 Northeast Strategic Technologies Center (CETENE), Cidade Universitária, Av. Prof. Luiz Freire, 1, Recife 50740-545, Brazil; milena.silva@cetene.gov.br

4 Rede Nordeste de Biotecnologia (RENORBIO), Federal Rural University of Pernambuco (UFRPE), Rua Dom Manuel de Medeiros, s/n, Dois Irmãos, Recife 52171-900, Brazil; charlesbronzo@yahoo.com.br

5 Escola UNICAP Icam Tech, Universidade Católica de Pernambuco (UNICAP), Rua do Príncipe, 526, Boa Vista, Recife 50050-900, Brazil; leonie.sarubbo@unicap.br

* Correspondence: converti@unige.it

check for updates

Citation: Casazza, A.A.; de Souza Oliveira, R.P.; Silva, M.F.d.; Solisio, C.; Farias, C.B.B.; Sarubbo, L.A.; Converti, A. Arthrospira platensis Cultivation in a Bench-Scale Helical Tubular Photobioreactor. Appl. Sci. 2022, 12, 1311. https://doi.org/ 10.3390/app12031311

Academic Editor: Francesca Scargiali

Received: 29 November 2021

Accepted: 23 January 2022

Published: 26 January 2022

Publisher's Note: MDPI stays neutral with regard to jurisdictional claims in published maps and institutional affiliations.

Copyright: (C) 2022 by the authors. Licensee MDPI, Basel, Switzerland. This article is an open access article distributed under the terms and conditions of the Creative Commons Attribution (CC BY) license (https:// creativecommons.org/licenses/by/ $4.0 /)$

\begin{abstract}
Cultivations of Arthrospira platensis were carried out to evaluate the $\mathrm{CO}_{2}$ capture capacity of this cyanobacterium under bench-scale conditions. For this purpose, the influence of light intensity on the microbial growth and the photosynthetic efficiency has been investigated in a helical photobioreactor. Five cultivations were performed at different photosynthetic photon flux densities $\left(23 \leq\right.$ PPFD $\leq 225 \mu \mathrm{mol}$ photons $\left.\mathrm{m}^{-2} \mathrm{~s}^{-1}\right)$ by fed-batch pulse-feeding pure carbon dioxide from a cylinder into the helicoidal photobioreactor. In particular, a range of PPFD (82-190 $\mu \mathrm{mol}$ photons $\mathrm{m}^{-2} \mathrm{~s}^{-1}$ ) was identified in which biomass concentration reached values (9-11 $\mathrm{g}_{\mathrm{DW}} \mathrm{L}^{-1}$ ) significantly higher than those reported in the literature for other configurations of closed photobioreactors. Furthermore, as A. platensis suspensions behave as Newtonian and non-Newtonian (pseudoplastic) fluids at very low and high biomass concentrations, respectively, a flow analysis was carried out for evaluating the most suitable mixing conditions depending on growth. The results obtained in this study appear to be very promising and suggest the use of this helicoidal photobioreactor configuration to reduce $\mathrm{CO}_{2}$ emissions from industrial gaseous effluents.
\end{abstract}

Keywords: carbon dioxide capture; fed-batch cultivation; Arthrospira platensis; helical tubular photobioreactor; light intensity

\section{Introduction}

Nowadays, microalgal mass cultivation in closed photobioreactors has attracted much interest [1]. Indeed, an overview of the literature published over the last two years up to the end of November 2021 has revealed that, contrary to what was observed in the last two decades, there has been an increase in the contributions related to "microalgal cultivation and closed photobioreactors", with no less than 761 scientific articles (based on the Science Direct search engine: http:/ / www.sciencedirect.com, accessed on 27 November 2021). A substantial portion of them deals with "Arthrospira platensis cultivation and closed photobioreactors" (215 scientific articles). Since this topic is an active and expanding field of research, targeted studies in this area deserve further investigation.

In this regard, intense research has been carried out on plant engineering to optimize the production system as well as on microbiological aspects to improve culture productivity through the isolation, selection, and genetic transformation of strains, with the goal of expanding the range of competitive high-value microalgal compounds [2-5]. The achievement of high productivity in microalgal mass with minimum operating costs is, in 
fact, fundamental to reduce the cost of valuable products and to broaden the commercial utilization of microalgae [6].

Microalgal cultivation technology has gained widespread attention because microalgae combine the renewable energy-capturing ability of photosynthesis with the high production rates of controlled microbial cultivation, which makes them potentially valuable organisms for cheap industrial production processes [5,7]. They represent the main natural source of useful and valuable molecules with numerous practical applications, for the majority of which the market is still developing; furthermore, the biotechnological use of microalgae is likely to extend to new areas. As for the application sectors, microalgae are nowadays used from human and animal nutrition [8] to aquaculture [9], pharmaceuticals [10], cosmetics [11], soil fertilization [12], environmental protection [13] including carbon dioxide fixation from industrial waste gases [14], biosorption of heavy metals [15], wastewater treatment [16], and production of biofuels [17].

Currently, the industrial priority is the development of pharmaceutical chemicals and biofuels [18]. Microalgae can, therefore, provide vast contributions on the future welfare of the planet by addressing the pressing issues of human health, food security, renewable energy sources, and global warming. Among the numerous high-quality products from biotechnology of microalgae, the most important regarding production amount and economic value is still the microalgal biomass itself. The worldwide yearly production of microalgal biomass is estimated to achieve 27,500 tons in 2024, with a turnover generation of about $1.1 \times 10^{9}$ US $\$$ per year [19]. Among the tens of thousands of species that are believed to exist, just a handful are cultivated in industrial quantities (i.e., in tons per year) [20]. Due to their global presence, microalgae are generally used for human and animal nutrition. The commercial applications are restricted to four species, among which is the cyanobacterium Arthrospira (Spirulina) platensis, the object of this study. More than $70 \%$ of the overall production of Arthrospira sp. biomass is addressed to human nutrition, mainly as a nutraceutical, owing to its high protein content and its excellent nutritional value [21-24]. In addition, over 50\% of the current world production of Arthrospira sp. is used as feed supplement for many types of animals [25].

To grow and exploit the potential of Arthrospira sp., efficient photobioreactors are required [26]. Currently, the commercial production of A. platensis is mainly performed in open systems [27], which are cheap and easy to operate, as they use solar radiation as a free source of energy [4]. However, they do not allow for reaching high biomass productivity, owing to the difficulty of keeping the optimum temperature; thus, they are restricted to the tropical and sub-tropical regions [28]. To overcome these problems, much widespread attention is now focused on closed systems, owing to their advantages over open cultivation systems (sterility, much greater control of cultivation conditions such as light intensity, carbon dioxide and nutrient levels, temperature, and higher biomass productivity). Particularly, a great deal of work has been done to develop suitable and efficient photobioreactors, such as flat-plate, tubular, vertical-column, and internally illuminated photobioreactors. Among them, tubular photobioreactors are often considered the most suitable ones for commercial large-scale mass cultures due to their large illumination surface area [29]. Most of these reactors are usually constructed with either glass or plastic transparent tubes, inside of which the culture is re-circulated either with mechanical pumps or preferably with airlifts. Regarding the shape, they can be horizontal/serpentine, vertical, L-shaped, nearly horizontal, conical, inclined, multi-tubular, or helical [30-36]. Some studies have shown that the parameters that most influence the growth in a tubular reactor are the tube size, mixing, and culture circulation [37], which in turn depend on the reactor configuration.

The global climate change is, today, one of the greatest environmental concerns. It is mainly due to the emission into the atmosphere of greenhouse gases, such as $\mathrm{CO}_{2}$ produced by the combustion of fossil fuels [5]. An attractive alternative to reduce carbon dioxide emissions could be the use of photosynthetic microorganisms able to utilize this pollutant as a carbon source for their growth [5,7]. From this point of view, the photoautotrophic 
cultivation of the cyanobacterium A. platensis would allow to produce valuable biomass using the $\mathrm{CO}_{2}$ from industrial processes and other human activities as a carbon source [38].

Light supply and distribution are undoubtedly the most important factors influencing the productivity of photoautotrophic cultures and represent the main source of energy for A. platensis. The first studies about the response of Arthrospira sp. to light were carried out by Zarrouk [39], who discovered that the growth of Arthrospira (Spirulina) maxima was inhibited at light intensity above 25-30 klux. Later, Vonshak [40] demonstrated that inhibition of $A$. platensis growth takes place at values of photosynthetic photon flux density (PPFD) exceeding 150-200 $\mathrm{mmol} \mathrm{m}^{-2} \mathrm{~s}^{-1}$.

Photoinhibition, which is a reduction of the photosynthetic activities caused by the exposition to high PPFD, was well studied and documented for algae as well [41,42]. When the flux of absorbed photons is too high, the concentration of high-energy electrons in the cell is excessive, and they cannot be consumed in the Calvin cycle. These electrons, by reacting with water and forming hydrogen peroxide, damage the cell structure [43]. Even in densely populated Arthrospira sp. outdoor cultivations, photoinhibition can be observed when light intensity is 60 to $70 \%$ of full sunlight [44]. Further studies carried out by changing light intensity in photoautotrophic cultivations suggested an optimum irradiance in the range of $30-50 \mathrm{~W} \mathrm{~m}^{-2}$ [43].

Based on this background, fed-batch cultivations were performed in this work in a bench-scale vertical helical photobioreactor to check the performance of this reactor configuration under different conditions of light intensity and $\mathrm{CO}_{2}$ feeding rate.

\section{Materials and Methods}

\subsection{Microorganism and Cultivation Medium}

The cyanobacterium used in this work, Arthrospira platensis UTEX LB 1926, was acquired from the University of Texas Culture Collection. The following information on this strain is provided by the supplier (https: / / utex.org/ products / utex-lb-1926? variant=309920 92299354\#details, accessed on 20 January 2022): UTEX Number: 1926; class: Cyanophyceae; medium: Enriched Seawater Medium (ES); origin: San Diego, CA, USA; location: Del Mar Slough; isolation: R.A. Lewin in 1969; deposition: F.T. Haxo in 10/12/72; relatives: UTEX LB 1928; PCC 7345, PCC reference strain; ATCC 29408; notes: deposited as CY-42; 11/5/70 to Haxo from Lewin; renamed by R.C. Starr; taxonomy available in [45]. The inoculum for the photobioreactor was prepared in the medium of Schlösser [46], containing $\left(\mathrm{g} \mathrm{L}^{-1}\right): \mathrm{NaHCO}_{3}$, $13.61 ; \mathrm{Na}_{2} \mathrm{CO}_{3}, 4.03 ; \mathrm{K}_{2} \mathrm{HPO}_{4}, 0.50 ; \mathrm{NaNO}_{3}, 2.50 ; \mathrm{K}_{2} \mathrm{SO}_{4}, 1.00 ; \mathrm{NaCl}, 1.00 ; \mathrm{MgSO}_{4} \cdot 7 \mathrm{H}_{2} \mathrm{O}$, $0.20 ; \mathrm{CaCl}_{2} \cdot 2 \mathrm{H}_{2} \mathrm{O}, 0.04$. The $\mathrm{pH}$ was 9.6. All nutrients were dissolved in distilled water containing (per liter): $6 \mathrm{~mL}$ of metal solution $\left(97 \mathrm{mg} \mathrm{FeCl} 3 \cdot 6 \mathrm{H}_{2} \mathrm{O}, 41 \mathrm{mg} \mathrm{M \textrm {Cl } _ { 2 }} \cdot 4 \mathrm{H}_{2} \mathrm{O}\right.$, $5 \mathrm{mg} \mathrm{ZnCl}$, $2 \mathrm{mg} \mathrm{CoCl} 2 \cdot 6 \mathrm{H}_{2} \mathrm{O}, 4 \mathrm{mg} \mathrm{Na} \mathrm{MoO}_{4} \cdot 2 \mathrm{H}_{2} \mathrm{O}$ ), $1 \mathrm{~mL}$ of micronutrient solution (50.0 mg Na 2 EDTA, $618 \mathrm{mg} \mathrm{H} \mathrm{HOO}_{3}, 19.6 \mathrm{mg} \mathrm{CuSO} \cdot 5 \mathrm{H}_{2} \mathrm{O}, 44.0 \mathrm{mg} \mathrm{ZnSO}_{4} \cdot 7 \mathrm{H}_{2} \mathrm{O}$, $20.0 \mathrm{mg} \mathrm{CoCl}{ }_{2} \cdot 6 \mathrm{H}_{2} \mathrm{O}, 12.6 \mathrm{mg} \mathrm{MnCl} 2 \cdot 4 \mathrm{H}_{2} \mathrm{O}, 12.6 \mathrm{mg} \mathrm{Na}_{2} \mathrm{MoO}_{4} \cdot 2 \mathrm{H}_{2} \mathrm{O}$ ), and $0.15 \mathrm{mg}$ of B12 vitamin.

Fed-batch cultivations were conducted in this medium lacking $\mathrm{NaHCO}_{3}$ and $\mathrm{Na}_{2} \mathrm{CO}_{3}$ by adding daily pure carbon dioxide as a carbon source, according to the pulse-feeding mode of operation.

\subsection{Culture Conditions}

To avoid the need for time-consuming re-inoculation in each run, the cultivations were performed one after the next using a working volume of $4.0 \mathrm{~L}$. The $\mathrm{pH}$ was initially adjusted and then controlled to $9.5 \pm 0.2$ by means of a $\mathrm{NaOH} 6.0 \mathrm{M}$ solution. The continuous light intensity was ensured by a variable number (from 1 to 4 ) of $40 \mathrm{~W}$-fluorescent lamps. The temperature was maintained at the optimum value for this microorganism $\left(30^{\circ} \mathrm{C}\right)$ [47] in a thermostatic chamber. $\mathrm{CO}_{2}$ additions were performed daily by bubbling the selected amount of pure gas directly into the medium from a cylinder with a flowmeter. 


\subsection{Analytical Methods}

The following parameters were determined during the experiments: $\mathrm{pH}$, temperature, and concentration of biomass. Dry biomass concentration $(X)$ was determined, after thrice washing and dilution with distilled water, from measurements of the culture absorbance at a wavelength of $560 \mathrm{~nm}\left(\mathrm{Abs}_{560}\right)$ by means of the calibration curve $\mathrm{Abs}_{560}=0.0024-0.1129 X\left(R^{2}=0.9921\right)$ [48]. Biomass concentration data have been expressed as the average of duplicate experiments. For this purpose, a Spectronic 21 UVVIS Spectrophotometer (Milton Roy Company, Rochester, NY, USA) was used. The culture $\mathrm{pH}$ was measured with a $\mathrm{pH}$ meter, model 211 (Hanna Instruments, Woonsocket, RI, USA). Light intensity was measured with an illuminance meter, model TL-1 (Minolta, Osaka, Japan), as photosynthetic photon flux density (PPFD) and expressed as $\mu \mathrm{mol}$ photons $\mathrm{m}^{-2} \mathrm{~s}^{-1}$. Measurements were performed at different points of the photobioreactor to ensure average PPFD values in the range of 23-225 $\mu \mathrm{mol}$ photons $\mathrm{m}^{-2} \mathrm{~s}^{-1}$ in order to avoid either light limitation or photoinhibition.

\subsection{Photobioreactor Design}

The closed photobiorector (Figure 1) consisted of a cylindrical-shaped glassy helical photostage $(1.5 \mathrm{~cm}$ in inner diameter with a glass thickness of $0.2 \mathrm{~cm})$, linked via PVC tubes $(10 \mathrm{~cm}, 1.6 \mathrm{~cm}$, and $0.25 \mathrm{~cm}$ of length, inner diameter, and thickness, respectively) to a 5.0-L Erlenmeyer flask closed with a cotton cap and placed on a magnetic stirrer at $200 \mathrm{rpm}$. Circulation was granted by an airlift mechanism capable of ensuring a recycling flowrate in the range of $0.34-1.4 \mathrm{~L} \mathrm{~min}^{-1}$. The vertical cylindrical photostage had a diameter of $1.6 \mathrm{~cm}$ and was $48 \mathrm{~cm}$ long. The overall volume was $4 \mathrm{~L}$ ( $0.6 \mathrm{~L}$ of photostage volume). The airlift system was set at a constant flowrate of $1.0 \mathrm{~L} \mathrm{~min}^{-1}$, ensuring a residence time of $4 \mathrm{~min}$. To avoid any atmospheric $\mathrm{CO}_{2}$ accumulation in the photobioreactor due to the air used in the airlift device, the ambient air was first passed through two $4 \mathrm{~L}$-closed vessels containing 2.0 $\mathrm{M} \mathrm{NaOH}$ and distilled water, respectively, and then through a drier containing $\mathrm{CaCl}_{2}$ before entering the system.

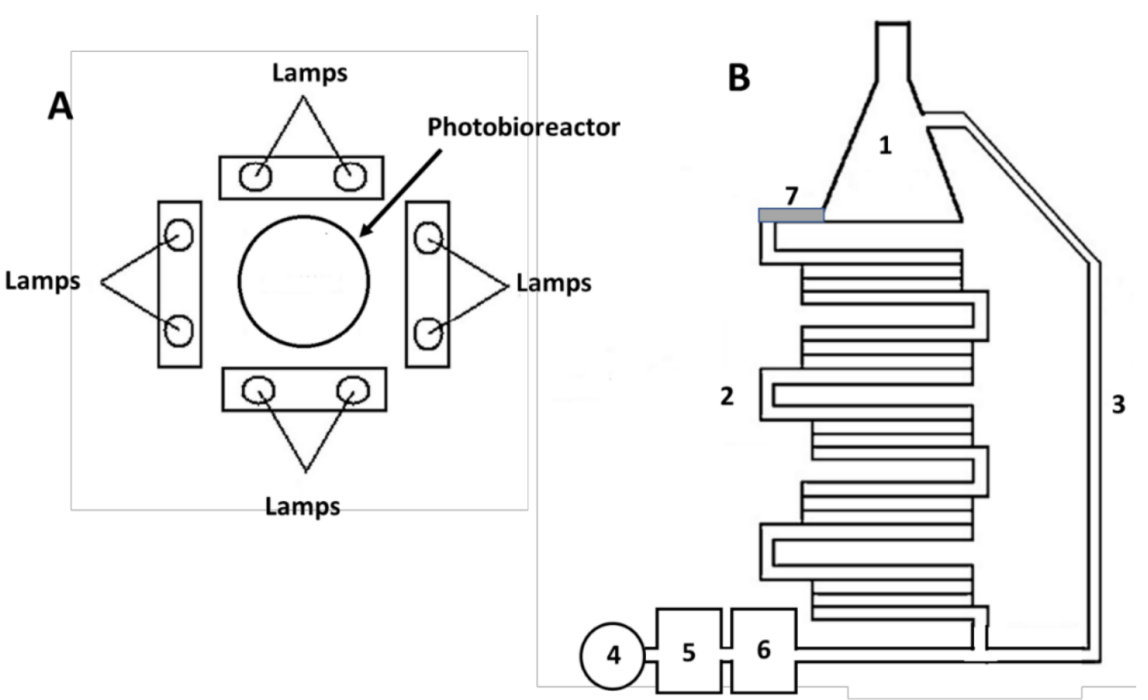

Figure 1. Schematics of the helicoidal photobioreactor utilized to cultivate Arthrospira platensis. Aerial (A) and frontal view (B). (1) 5.0-L Erlenmeyer flask; (2) cylindrical-shaped glassy helical photostage; (3) vertical cylindrical photostage; (4) air pump; (5) $\mathrm{NaOH}$ solution; (6) $\mathrm{CaCl}_{2}$-containing closed vessels; (7) PVC connection.

\subsection{Calculation of Growth Parameters}

The start-up phase of growth was investigated since the beginning of each cultivation up to the achievement of pseudo-steady state conditions. 
The maximum cell concentration $\left(X_{\mathrm{m}}\right)$ was determined at the end of start-up and the beginning of the steady state by absorbance measurements, as previously described.

The average volumetric cell productivity of the start-up $\left(P_{\mathrm{X}}\right)$ was estimated as the ratio of the difference between $X_{\mathrm{m}}$ and the initial biomass concentration $\left(X_{0}\right)$ to the whole duration of the start-up $\left(t_{\mathrm{m}}\right)$ :

$$
P_{\mathrm{X}}=\frac{X_{\mathrm{m}}-X_{0}}{t_{\mathrm{m}}}
$$

The average specific growth rate $\left(\mu_{X}\right)$ of the microorganism was estimated by the equation:

$$
\mu_{\mathrm{X}}=\frac{1}{t_{\mathrm{m}}} \ln \frac{X_{\mathrm{m}}}{X_{0}}
$$

The photosynthetic efficiency was calculated according to the following procedure. The PPFD, expressed in $\mu \mathrm{mol}$ photons $\mathrm{m}^{-2} \mathrm{~s}^{-1}$, was converted to photosynthetic active radiation (PAR), expressed in $\mathrm{kJ} \mathrm{m}^{-2} \mathrm{day}^{-1}$, using the conversion factor reported by Hall and Scurlock [49] for cold fluorescent light lamps (18.78 kJ s day $\left.{ }^{-1}\right)$. Multiplying PPFD by the area exposed to the light $\left(0.164 \mathrm{~m}^{2}\right)$, it was possible to obtain the input of PAR (IPAR), which allowed estimating the photosynthetic efficiency (PE) through the equation:

$$
\mathrm{PE}=\frac{r_{\mathrm{D}} H_{\mathrm{D}}}{\mathrm{IPAR}} \times 100
$$

where $r_{\mathrm{D}}$ is the daily biomass production $\left(\mathrm{g}_{\mathrm{DW}}\right.$ day $\left.^{-1}\right)$ and $H_{\mathrm{D}}=21.01 \mathrm{~kJ} \mathrm{gDW}^{-1}$ is the enthalpy of dried biomass [50,51].

\section{Results and Discussion}

Five cultivations of Arthrospira platensis were performed in duplicate at different photosynthetic photon flux densities $\left(23 \leq\right.$ PPFD $\leq 225 \mu \mathrm{mol}$ photons $\left.\mathrm{m}^{-2} \mathrm{~s}^{-1}\right)$ by fedbatch pulse-feeding pure carbon dioxide from a cylinder into the helicoidal photobioreactor. In this way, it was possible to verify the influence of this variable on both the start-up profile and the pseudo-steady state biomass concentration $\left(X_{\mathrm{m}}\right)$, cell productivity $\left(P_{\mathrm{X}}\right)$, and photosynthetic efficiency (PE) of this system.

The start-up results of these cultivations in terms of biomass concentration and photosynthetic efficiency are illustrated in Figures 2 and 3, while those of parameters calculated at the beginning of pseudo-steady state conditions are summarized in Table 1.

In all the cultivations, biomass grew following the typical sigmoid behavior of batch growth curves and reached a threshold cell concentration under steady-state conditions, which may have been the result, depending on the light intensity conditions, either of lack of a limiting substrate or of possible photoinhibition occurrence. The maximum value of this growth parameter $\left(X_{\mathrm{m}}=11.0 \mathrm{~g}_{\mathrm{DW}} \mathrm{L}^{-1}\right)$ was observed at PPFD $=190 \mu \mathrm{mol}$ photons $\mathrm{m}^{-2} \mathrm{~s}^{-1}$, which suggests that no photoinhibition occurred under these conditions, confirming the results of previous studies on this cyanobacterium $[43,52]$.

The specific growth rate $\left(\mu_{\mathrm{X}}\right)$ also increased with PPFD, but it reached a maximum value $\left(0.62\right.$ day $\left.^{-1}\right)$ at quite lower PPFD $\left(61 \mu \mathrm{mol}\right.$ photons $\left.\mathrm{m}^{-2} \mathrm{~s}^{-1}\right)$, beyond which a quick decline was observed. This result suggests that the lack of a carbon source rather than photoinhibition may have been the growth limiting factor up to PPFD $=190 \mu \mathrm{mol}$ photons $\mathrm{m}^{-2} \mathrm{~s}^{-1}$. However, by further increasing the light intensity (PPFD $=225 \mu \mathrm{mol}$ photons $\mathrm{m}^{-2} \mathrm{~s}^{-1}$ ), the photoinhibition likely became the predominant factor because of the excess photon flux on both photosystems of the cyanobacterium with their consequent damage [43].

The volumetric cell productivity appeared to be influenced by PPFD, according to the following empirical second-degree polynomial equation:

$$
P_{\mathrm{X}}=6.5 \times 10^{-3} \mathrm{PPFD}-2.0 \times 10^{-5} \mathrm{PPFD}^{2}\left(\mathrm{R}^{2}=0.8064\right)
$$


while the photosynthetic efficiency clearly decreased with increasing PPFD. However, despite the highest value of PE occurred at the lowest light intensity, these conditions led to the lowest $X_{\mathrm{m}}$ value.


Figure 2. Time behaviors of biomass concentration $(X, \bullet)$ and photosynthetic efficiency $(\mathrm{PE}, \square)$ along fed-batch pulse-feeding cultivation of Arthrospira platensis in a helical photobioreactor at a PPD of (a) $23 \mu \mathrm{mol}$ photons $\mathrm{m}^{-2} \mathrm{~s}^{-1}$ and (b) $61 \mu \mathrm{mol}$ photons $\mathrm{m}^{-2} \mathrm{~s}^{-1}$. 

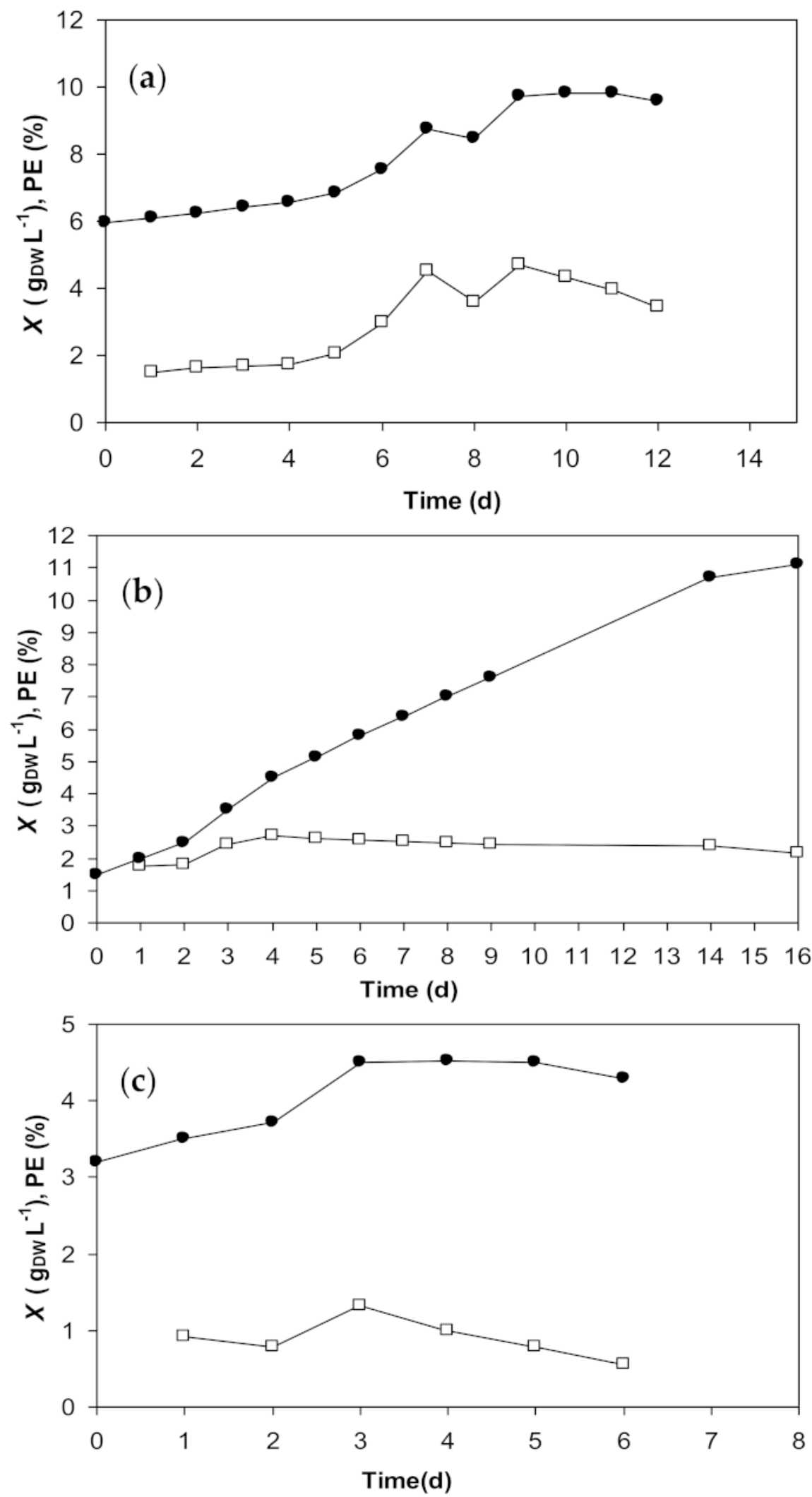

Figure 3. Time behaviors of biomass concentration $(X, \bullet)$ and photosynthetic efficiency $(P E, \square)$ along fed-batch pulse-feeding cultivation of Arthrospira platensis in a helical photobioreactor at PPFD of (a) $82 \mu \mathrm{mol}$ photons $\mathrm{m}^{-2} \mathrm{~s}^{-1}$, (b) $190 \mu \mathrm{mol}$ photons $\mathrm{m}^{-2} \mathrm{~s}^{-1}$, and (c) $225 \mu \mathrm{mol}$ photons $\mathrm{m}^{-2} \mathrm{~s}^{-1}$. 
Table 1. Results of batch Arthrospira platensis cultivations carried out in the helical photobioreactor under different light intensities.

\begin{tabular}{|c|c|c|c|c|}
\hline $\begin{array}{c}\text { PPFD }^{1} \\
\left(\mu \mathrm{mol} \text { photons } \mathrm{m}^{-2} \mathrm{~s}^{-1}\right)\end{array}$ & $\begin{array}{c}X_{\mathrm{m}}^{2} \\
\left(\mathrm{~g}_{\mathrm{DW}} \mathrm{L}^{-1}\right)\end{array}$ & $\begin{array}{c}P_{X}^{3} \\
\left(g_{D W} L^{-1} \text { day }^{-1}\right)\end{array}$ & $\begin{array}{c}\mu_{\mathrm{X}}^{4} \\
\left(\mathrm{day}^{-1}\right)\end{array}$ & $\begin{array}{l}\mathrm{PE}^{5} \\
(\%)\end{array}$ \\
\hline 23 & $3.3 \pm 0.3$ & $0.21 \pm 0.03$ & 0.16 & $10.4 \pm 0.94$ \\
\hline 61 & $6.1 \pm 0.5$ & $0.23 \pm 0.02$ & 0.62 & $2.49 \pm 0.20$ \\
\hline 82 & $9.8 \pm 0.7$ & $0.42 \pm 0.03$ & 0.55 & $4.70 \pm 0.34$ \\
\hline 190 & $11.0 \pm 0.9$ & $0.59 \pm 0.06$ & 0.28 & $2.62 \pm 0.21$ \\
\hline 225 & $4.5 \pm 0.5$ & $0.43 \pm 0.05$ & 0.11 & $1.31 \pm 0.14$ \\
\hline
\end{tabular}

${ }^{1}$ Photosynthetic photon flux density; ${ }^{2}$ maximum cell concentration; ${ }^{3}$ maximum cell productivity; ${ }^{4}$ specific growth rate; ${ }^{5}$ photosynthetic efficiency. Values of $X_{\mathrm{m}}, P_{\mathrm{X}}$, and $\mathrm{PE}$ are expressed as the average values of duplicate runs \pm standard deviation.

Considering that, on an industrial scale, free sunlight is used as an energy source, to optimize the system for stable long term-production of biomass, the best conditions to ensure the maximum cell growth in the absence of any photoinhibition should be searched.

As mentioned earlier, these conditions were ensured in the proposed photobioreactor configuration at PPFD $=190 \mu \mathrm{mol}$ photons $\mathrm{m}^{-2} \mathrm{~s}^{-1}$, under which we obtained $X_{\mathrm{m}}=11.0 \mathrm{~g}_{\mathrm{DW}} \mathrm{L}^{-1}$, whereas the maximum photosynthetic efficiency $(\mathrm{PE}=10.4 \%)$ was obtained at the lowest light intensity (PPFD $=23 \mu \mathrm{mol}$ photons $\mathrm{m}^{-2} \mathrm{~s}^{-1}$ ). This finding demonstrates that an increase in PPFD, under non-photoinhibiting conditions, results in an increased dissipation of energy, which is not utilized for photosynthesis. Soletto et al. [53] observed a slightly lower $\mathrm{PE}$ in a similar horizontally arranged helical reactor $(\mathrm{PE}=9.4 \%)$ but at a higher PPFD $\left(125 \mu \mathrm{mol}\right.$ photons $\left.\mathrm{m}^{-2} \mathrm{~s}^{-1}\right)$; however, the photoinhibition threshold was substantially lower (PPFD $=166 \mu \mathrm{mol}$ photons $\mathrm{m}^{-2} \mathrm{~s}^{-1}$ ).

A comparison with literature data shows that the helical configuration under consideration was able to guarantee a cell concentration substantially higher than those reported for open ponds $\left(X_{\mathrm{m}}=0.84-1.21 \mathrm{~g}_{\mathrm{DW}} \mathrm{L}^{-1}\right)$ [22] and two-plane tubular reactors $\left(X_{\mathrm{m}}=4.2 \mathrm{~g}_{\mathrm{DW}} \mathrm{L}^{-1}\right)$ [54]. In addition, although Duarte et al. [55] obtained the best growth parameters for Arthrospira sp. LEB 18 cultures in a tubular photobioreactor with a maximum biomass concentration about $63 \%$ higher $\left(1.22 \mathrm{~g}_{\mathrm{DW} \mathrm{L}} \mathrm{L}^{-1}\right)$ than in a raceway pond $\left(0.72 \mathrm{~g}_{\mathrm{DW} \mathrm{L}} \mathrm{L}^{-1}\right)$, these values were lower than those found in the present study.

From the results of $\mu_{\mathrm{X}}$ listed in Table 1, one can propose the following empirical second-degree polynomial equation relating this kinetic parameter to PPFD:

$$
\mu_{\mathrm{X}}=0.011 \mathrm{PPFD}-5.0 \times 10^{-5} \mathrm{PPFD}^{2}\left(\mathrm{R}^{2}=0.8498\right)
$$

which, together with Equation (4), may be usefully employed to optimize this process on an industrial scale.

Equations (4) and (5) allowed for estimating two different PPFD ranges (100-120 and 155-170 $\mu$ mol photons $\mathrm{m}^{-2} \mathrm{~s}^{-1}$ ) within which cell productivity and specific growth rate reached maximum values of $0.527-0.528 \mathrm{gDW} \mathrm{L}^{-1}$ day $^{-1}$ and $0.600-0.605$ day $^{-1}$, respectively.

A flow analysis was finally done to check the suitability of mixing in the photobioreactor because $A$. platensis suspensions behave as Newtonian and non-Newtonian (pseudoplastic) fluids at low $\left(<2 \mathrm{~g} \mathrm{~L}^{-1}\right)$ and high $\left(>4 \mathrm{~g} \mathrm{~L}^{-1}\right)$ biomass concentrations [56], respectively. For this purpose, to investigate all the mixing conditions possibly occurring in the photobioreactor, the Reynolds number $\left(N_{\mathrm{Re}}\right)$ was estimated, according to that study, at culture flowrates in the range of the selected airlift system $\left(0.33-1.4 \mathrm{~L} \mathrm{~min}^{-1}\right)$ using two biomass concentrations $\left(0.05\right.$ and $\left.10 \mathrm{~g}_{\mathrm{DW} \mathrm{L}} \mathrm{L}^{-1}\right)$ representative of poor and excellent growth conditions, which were below and over the above threshold values, respectively.

As can be seen in Figure 4, the $N_{\operatorname{Re}}$ would range from about 100 and 600 under the former growth conditions and about 600 and 2500 under the latter, with respective values of about 400 and 1900 at the recycling flowrate selected for this study $\left(1.0 \mathrm{~L} \mathrm{~min}^{-1}\right)$, corresponding to a residence time of $4 \mathrm{~min}$ and a culture speed of about $6.0 \mathrm{~m} \mathrm{~min}^{-1}$. Even 
though the higher value (1900) is about 5\% lower than that (2100) required to ensure a turbulence regime [56], which is often considered preferable for satisfactory mixing, it is worth reminding that the mechanical stress under these conditions could lead to the damage of cyanobacterial thricomes [57].

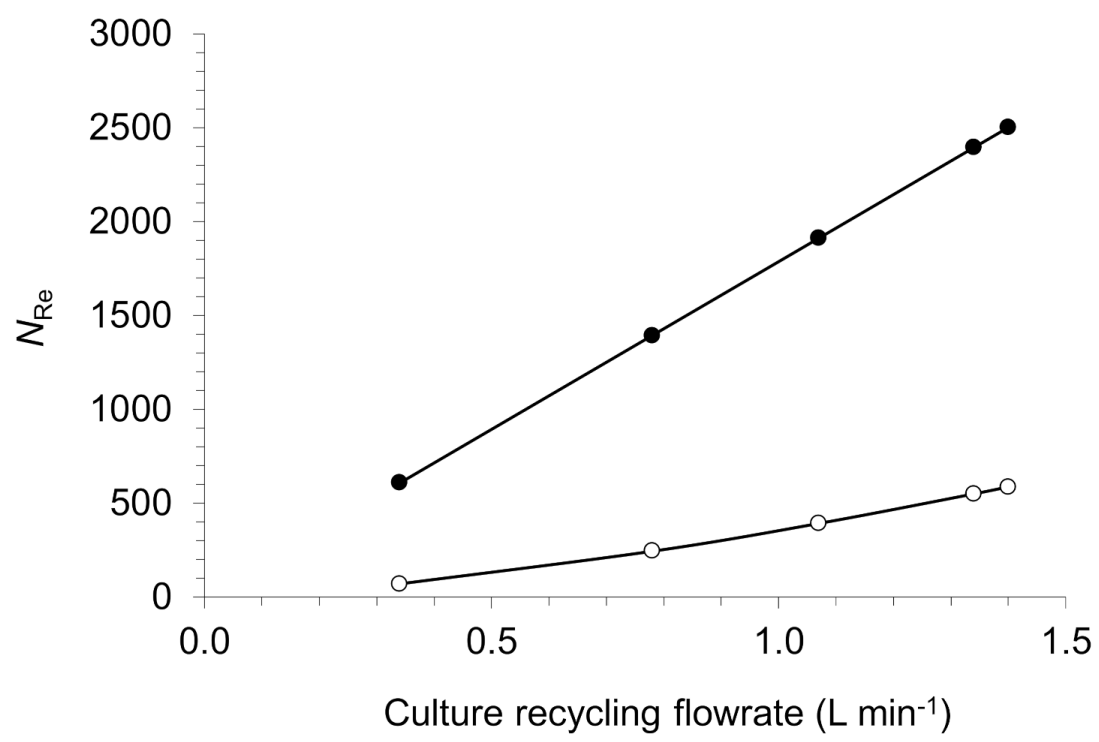

Figure 4. Reynolds number calculated for the helical photobioreactor as a function of the culture recycling flowrate at two different cell concentrations $\left(g_{D W} L^{-1}\right)$ : $(\bigcirc) 0.05 ;(\bullet) 10.0$.

\section{Conclusions}

Overall, the results obtained in this study appear very promising and suggest the use of this helical photobioreactor configuration to reduce $\mathrm{CO}_{2}$ emissions from industrial gaseous effluents. A wide range of light intensity $\left(82-190 \mu \mathrm{mol}\right.$ photons $\left.\mathrm{m}^{-2} \mathrm{~s}^{-1}\right)$ was identified in which biomass concentration reached values $\left(9-11 \mathrm{gDW} \mathrm{L}^{-1}\right)$ significantly higher than those reported in the literature for other configurations of closed photobioreactors, which constitutes a further advantage of the system, considering the natural variability of this parameter in nature. A flow analysis that was performed to check the suitability of mixing within the photobioreactor suggested that such a good performance may be ascribed to the ability of the airlift system to minimize mechanical stress to cells. Remembering that the optimal results of this work were obtained under lower light intensity than sunlight, with the due precautions they can be useful for designing a real-scale plant to reduce carbon dioxide emissions from industrial gaseous effluents. Future efforts in this field will deal with continuous application of this photobioreactor configuration, either for the autotrophic capture of $\mathrm{CO}_{2}$ from gaseous emissions or for the mixotrophic treatment of industrial wastewater.

Author Contributions: Conceptualization, A.C., A.A.C., C.B.B.F., R.P.d.S.O. and M.F.d.S.; methodology, A.A.C., C.B.B.F. and M.F.d.S.; software, A.A.C. and M.F.d.S.; validation, A.A.C., R.P.d.S.O. and M.F.d.S.; formal analysis, A.A.C., C.S. and M.F.d.S.; investigation, A.A.C., A.C., R.P.d.S.O. and M.F.d.S.; resources, C.S. and A.C.; data curation, A.A.C., A.C. and M.F.d.S.; writing-original draft preparation, R.P.d.S.O., A.A.C. and M.F.d.S.; writing-review and editing, A.A.C., C.S., A.C. and L.A.S.; visualization, A.A.C., L.A.S. and C.B.B.F.; supervision, C.S. and A.C.; project administration, C.S. and A.C.; funding acquisition, C.S. and A.C. All authors have read and agreed to the published version of the manuscript.

Funding: This research was funded by the University of Genoa, grant number FRA 2020.

Institutional Review Board Statement: Not applicable.

Informed Consent Statement: Not applicable. 
Data Availability Statement: The data presented in this study are available on request from the corresponding author.

Conflicts of Interest: The authors declare no conflict of interest.

\section{References}

1. Kirnev, P.C.S.; Carvalho, J.C.; Vandenberghe, L.P.S.; Karp, S.G.; Soccol, C.R. Technological mapping and trends in photobioreactors for the production of microalgae. World J. Microbiol. Biotechnol. 2020, 36, 42. [CrossRef]

2. Nethravathy, M.U.; Jitendra, G.M.; Sandeep, N.M.; Ajam, Y.S. Recent advances in microalgal bioactives for food, feed, and healthcare products: Commercial potential, market space, and sustainability. Compr. Rev. Food Sci. Food Saf. 2019, 18, 1882-1897. [CrossRef]

3. Veerabadhran, M.; Natesan, S.; MubarakAli, D.; Xu, S.; Yang, F. Using different cultivation strategies and methods for the production of microalgal biomass as a raw material for the generation of bioproducts. Chemosphere 2021, 285, 131436. [CrossRef] [PubMed]

4. Hoyo, A.; Rodríguez-Miranda, E.; Guzmán, J.L.; Acién, F.G.; Berenguel, M.; Moreno, J.C. A computer-based tool to simulate raceway photobioreactors for design, operation and control purposes. Comput. Chem. Eng. 2022, 156, 107572. [CrossRef]

5. Peter, A.P.; Koyande, A.K.; Chew, K.W.; Ho, S.-H.; Chen, W.-H.; Chang, J.-S.; Krishnamoorthy, R.; Banat, F.; Show, P.L. Continuous cultivation of microalgae in photobioreactors as a source of renewable energy: Current status and future challenges. Renew. Sust. Energ. Rev. 2022, 154, 111852. [CrossRef]

6. Spennati, E.; Casazza, A.A.; Converti, C. Winery wastewater treatment by microalgae to produce low-cost biomass for energy production purposes. Energies 2020, 13, 2490. [CrossRef]

7. Wang, T.H.; Dong, C.-D.; Lin, J.-Y.; Chen, C.-W.; Chang, J.-S.; Kim, H.; Huang, C.-P.; Hung, C.-M. Recent advances in carbon dioxide conversion: A circular bioeconomy perspective. Sustainability 2021, 13, 6962. [CrossRef]

8. Becker, E.W. Microalgae for Human and Animal Nutrition. In Handbook of Microalgal Culture: Applied Phycology and Biotechnology, 2nd ed.; Richmond, A., Hu, Q., Eds.; Wiley-Blackwell: Hoboken, NJ, USA, 2013; Chapter 25; pp. 461-503. [CrossRef]

9. Roy, S.S.; Pal, R. Microalgae in aquaculture: A review with special references to nutritional value and fish dietetics. Proc. Zool. Soc. 2015, 68, 1-8. [CrossRef]

10. Jha, D.; Jain, V.; Sharma, B.; Kant, A.; Garlapati, V.K. Microalgae-based pharmaceuticals and nutraceuticals: An emerging field with immense market potential. Chem. Bio. Eng. 2017, 4, 257-272. [CrossRef]

11. Yarkent, C.; Gürlek, C.; Oncel, S.S. Potential of microalgal compounds in trending natural cosmetics: A review. Sust. Chem. Pharm. 2020, 17, 100304. [CrossRef]

12. Suleiman, A.K.A.; Silva Lourenço, K.; Clark, C.; Lima Luz, R.; Ribeiro da Silva, G.H.; Vet, L.E.M.; Cantarella, H.; Fernandes, T.V.; Kuramae, E.E. From toilet to agriculture: Fertilization with microalgal biomass from wastewater impacts the soil and rhizosphere active microbiomes, greenhouse gas emissions and plant growth. Resour. Conserv. Recycl. 2020, 161, 104924. [CrossRef]

13. Dębowski, M.; Zieliński, M.; Kazimierowicz, J.; Kujawska, N.; Talbierz, S. Microalgae cultivation technologies as an opportunity for bioenergetic system development-Advantages and limitations. Sustainability 2020, 12, 9980. [CrossRef]

14. Gonzalo Ibrahim, F.; Muñoz Torre, R.; Llamas Moya, B.; de Godos Crespo, I. Carbon Dioxide Capture from Carbon Dioxide-Rich Gases by Microalgae. In From Biofiltration to Promising Options in Gaseous Fluxes Biotreatment, 1st ed.; Soreanu, G., Dumont, É., Eds.; Elsevier: Amsterdam, The Netherlands, 2020; Chapter 18; pp. 373-396. [CrossRef]

15. Ubando, A.T.; Africa, A.d.M.; Maniquiz-Redillas, M.C.; Culaba, A.B.; Chen, W.-H.; Chang, J.-S. Microalgal biosorption of heavy metals: A comprehensive bibliometric review. J. Hazard. Mater. 2021, 402, 123431. [CrossRef] [PubMed]

16. Wollmann, F.; Dietze, S.; Ackermann, J.-U.; Bley, T.; Walther, T.; Steingroewer, J.; Krujatz, F. Microalgae wastewater treatment: Biological and technological approaches. Eng. Life Sci. 2019, 19, 860-871. [CrossRef] [PubMed]

17. Hossain, N.; Mahlia, T.M.I.; Saidur, R. Latest development in microalgae-biofuel production with nano-additives. Biotechnol. Biofuels 2019, 12, 125. [CrossRef]

18. Escudero-Oñate, C.; Ferrando-Climent, L. Microalgae for Biodiesel Production and Pharmaceutical Removal from Water. In Nanoscience and Biotechnology for Environmental Applications. Environmental Chemistry for a Sustainable World; Gothandam, K., Ranjan, S., Dasgupta, N., Lichtfouse, E., Eds.; Springer: Cham, Switzerland, 2019; Volume 22, pp. 1-28. [CrossRef]

19. Dmytryk, A.; Chojnacka, K.; Rój, E. The methods of Algal Biomass Extraction: Toward the Application. In Algae Biomass: Characteristics and Applications; Chojnacka, K., Wieczorek, P.P., Schroeder, G., Michalak, I., Eds.; Springer: Basel, Switzerland, 2018; Chapter 5; pp. 49-56. [CrossRef]

20. Olaizola, M. Commercial development of microalgal biotechnology: From the test tube to the marketplace. Biomol. Eng. 2003, 20, 459-466. [CrossRef]

21. Matsudo, M.C.; Bezerra, R.P.; Sato, S.; Perego, P.; Converti, A.; Carvalho, J.C.M. Repeated fed-batch cultivation of Arthrospira (Spirulina) platensis using urea as nitrogen source. Biochem. Eng. J. 2009, 43, 52-57. [CrossRef]

22. Delrue, F.; Alaux, E.; Moudjaoui, L.; Gaignard, C.; Fleury, G.; Perilhou, A.; Richaud, P.; Petitjean, M.; Sassi, J.F. Optimization of Arthrospira platensis (Spirulina) growth: From laboratory scale to pilot scale. Fermentation 2017, 3, 59. [CrossRef]

23. Mitra, M.; Mishra, S. Multiproduct biorefinery from Arthrospira spp. towards zero waste: Current status and future trends. Bioresour. Technol. 2019, 291, 121928. [CrossRef] 
24. Caporgno, M.P.; Mathys, A. Trends in microalgae incorporation into innovative food products with potential health benefits. Front. Nutr. 2018, 5, 58. [CrossRef]

25. Sathasivam, R.; Radhakrishnan, R.; Hashem, A.; Abd_Allah, E.F. Microalgae metabolites: A rich source for food and medicine Saudi J. Biol. Sci. 2019, 26, 709-722. [CrossRef]

26. Ugwu, C.U.; Aoyagi, H.; Uchiyama, H. Photobioreactors for mass cultivation of algae. Bioresour. Technol. 2008, 99, 4021-4028. [CrossRef]

27. Gupta, P.L.; Lee, S.M.; Choi, H.J. A mini review: Photobioreactors for large scale algal cultivation. World J. Microbiol. Biotechnol. 2015, 31, 1409-1417. [CrossRef] [PubMed]

28. Jiménez, C.; Cossío, B.R.; Niell, F.X. Relationship between physicochemical variables and productivity in open ponds for the production of Spirulina: A predictive model of algal yield. Aquaculture 2003, 221, 331-345. [CrossRef]

29. Chisti, Y. Microalgae as sustainable cell factories. Environ. Eng. Manag. J. 2006, 5, 261-274. [CrossRef]

30. Hall, D.O.; Fernandéz, F.G.A.; Guerrero, E.C.; Rao, K.K.; Molina Grima, E. Outdoor helical tubular photobioreactors for microalgal production: Modelling of fluid-dynamics and mass transfer and assessment of biomass productivity. Biotechnol. Bioeng. 2003, 82, 62-73. [CrossRef] [PubMed]

31. Carlozzi, P.; Pushparaj, B.; Degl'Innocenti, A.; Capperucci, A. Growth characteristics of Rhodopseudomonas palustris cultured outdoors, in an underwater tubular photobioreactor, and investigation of photosynthetic efficiency. Appl. Microbiol. Biotechnol. 2006, 73, 789-795. [CrossRef]

32. Frumento, D.; Aliakbarian, B.; Casazza, A.A.; Al Arni, S.; da Silva, M.F.; Converti, A. Chlorella vulgaris as a lipid source: Cultivation on air and seawater-simulating medium in a helicoidal photobioreactor. Biotechnol. Prog. 2016, 32, 279-284. [CrossRef] [PubMed]

33. Vunjak-Novakovic, G.; Kim, Y.; Wu, X.; Berzin, I.; Merchhuk, J.C. Air-lift bioreactors for algal growth on flue gas: Mathematical modeling and pilot-plant studies. Ind. Eng. Chem. Res. 2005, 44, 6154-6163. [CrossRef]

34. Chae, S.R.; Hwang, E.J.; Shin, H.S. Single cell protein production of Euglena gracilis and carbon dioxide fixation in an innovative photo-bioreactor. Bioresour. Technol. 2006, 97, 322-329. [CrossRef]

35. Li, M.J.; Wang, R.L.; Yang, Y.W.; Chen, J.X. Numerical and experimental analysis of optimized conical flask photobioreactor structures to improve liquid-gas two-phase distribution and microalgae carbon sequestration. Appl. Therm. Eng. 2020, 180, 115855. [CrossRef]

36. Sukáčová, K.; Lošák, P.; Brummer, V.; Máša, V.; Vícha, D.; Zavřel, T. Perspective design of algae photobioreactor for greenhousesA comparative study. Energies 2021, 14, 1338. [CrossRef]

37. Molina, E.; Fernández, J.; Acién, F.G.; Chisti, Y. Tubular photobioreactor design for algal cultures. J. Biotechnol. 2001, 92, 113-131. [CrossRef]

38. Kishi, M.; Yamada, Y.; Katayama, T.; Matsuyama, T.; Toda, T. Carbon mass balance in Arthrospira platensis culture with medium recycle and high $\mathrm{CO}_{2}$ supply. Appl. Sci. 2020, 10, 228. [CrossRef]

39. Zarrouk, C. Contribution à l'Ėtude d'Une Cyanophycèe. Influence de Divers Facteurs Physiques et Chimiques sur la Croissance et la Photosynthèse de Spirulina Maxima (Setch. et Gardner) Geitler. Ph.D. Thesis, University of Paris, Paris, France, 1966.

40. Vonshak, A. Spirulina: Growth, Physiology and Biochemistry. In Spirulina Platensis (Arthrospira): Physiology, Cell-Biology and Biotechnology; Vonshak, A., Ed.; Taylor \& Francis: London, UK, 1997; pp. 43-65.

41. Demeter, S.; Janda, T.; Kovács, L.; Mende, D.; Wiessner, W. Effects of in vivo $\mathrm{CO}_{2}$-depletion on electron transport and photoinhibition in the green algae Chlamydobotrys stellata and Chlamydomonas reinhardtii. Biochim. Biophys. Acta 1995, 1229, 166-174. [CrossRef]

42. Häder, D.P.; Lebert, M.; Flores-Moya, A.; Jiménez, C.; Mercado, J.; Salles, S.; Aguilera, J.; Figuero, F.L. Effects of solar radiation on the photosynthetic activity of the red alga Corallina elongata Ellis et Soland. J. Photochem. Photobiol. B-Biol. 1997, 37, 196-202. [CrossRef]

43. Chojnacka, K.; Noworyta, A. Evaluation of Spirulina sp. growth in photoautotrophic, heterotrophic and mixotrophic cultures Enzyme Microb. Technol. 2004, 34, 461-465. [CrossRef]

44. Vonshak, A.; Richmond, A. Mass production of the blue-green alga Spirulina: An overview. Biomass 1988, 15, 233-247. [CrossRef]

45. Rippka, R.; Deruelles, J.; Waterbury, J.B.; Herdman, M.; Stanier, R.Y. Generic assignments, strain histories and properties of pure cultures of cyanobacteria. J. Gen. Microbiol. 1979, 111, 1-61. [CrossRef]

46. Schlösser, U.G. Sammlung von Algenkulturen. Ber. Deutsch. Bot. Ges. 1982, 95, S181-S276. [CrossRef]

47. da Silva, M.F.; Casazza, A.A.; Ferrari, P.F.; Perego, P.; Bezerra, R.P.; Converti, A.; Porto, A.L.F. A new bioenergetic and thermodynamic approach to batch photoautotrophic growth of Arthrospira (Spirulina) platensis in different photobioreactors and under different light conditions. Bioresour. Technol. 2016, 207, 220-228. [CrossRef] [PubMed]

48. Casazza, A.A.; Ferrari, P.F.; Aliakbarian, B.; Converti, A.; Perego, P. Effect of UV radiation or titanium dioxide on polyphenol and lipid contents of Arthrospira (Spirulina) platensis. Algal Res. 2015, 12, 308-315. [CrossRef]

49. Hall, D.O.; Scurlock, J.M.O. Biomass Production and Data. In Photosynthesis and Production in a Changing Environment; Hall, D.O., Scurlock, J.M.O., Bolhar-Nordenkampf, H.R., Leegood, R.C., Long, S.P., Eds.; Chapman \& Hall: London, UK, 1993 ; pp. $425-444$.

50. Watanabe, Y.; Saiki, H. Development of a photobioreactor incorporating Chlorella sp. for removal of $\mathrm{CO}_{2}$ in stack gas. Energy Convers. Manag. 1997, 38, S499-S503. [CrossRef]

51. Converti, A.; Lodi, A.; Del Borghi, A.; Solisio, C. Cultivation of Spirulina platensis in a combined airlift-tubular system. Biochem. Eng. J. 2006, 32, 13-18. [CrossRef] 
52. Vonshak, A.; Laorawat, S.; Bunnag, B.; Tanticharoen, M. The effect of light availability on the photosynthetic activity and productivity of outdoor cultures of Arthrospira platensis (Spirulina). J. Appl. Phycol. 2014, 26, 1309-1315. [CrossRef]

53. Soletto, D.; Binaghi, L.; Lodi, A.; Carvalho, J.C.M.; Converti, A. Batch and fed-batch cultivations of Spirulina platensis using ammonium sulphate and urea as nitrogen sources. Aquaculture 2005, 243, 217-224. [CrossRef]

54. Torzillo, G.; Carlozzi, P.; Pushparaj, B.; Montaini, E.; Materassi, R. A two-plane tubular photobioreactor for outdoor culture of Spirulina. Biotechnol. Bioeng. 1993, 42, 891-898. [CrossRef]

55. Duarte, J.H.; Fanka, L.S.; Costa, J.A.V. $\mathrm{CO}_{2}$ biofixation via Spirulina sp. cultures: Evaluation of initial biomass concentration in tubular and raceway photobioreactors. BioEnergy Res. 2020, 13, 939-943. [CrossRef]

56. Torzillo, G. Tubular Bioreactors. In Spirulina platensis (Arthrospira): Physiology, Cell-Biology and Biotechnology; Vonshak, A., Ed.; Taylor \& Francis: London, UK, 1997; pp. 101-115.

57. Oliveira, S.; Clemente, A.; Menezes, I.; Gois, A.; Carloto, I.; Lawton, L.; Capelo-Neto, J. Hazardous cyanobacteria integrity response to velocity gradient and powdered activated carbon in water treatment plants. Sci. Total Environ. 2021, $773,145110$. [CrossRef] 